\title{
Heidegger, or the neglect of boundaries
}

\author{
U. Strohmayer \\ School of Geography and Archaeology, National University of Ireland, Galway, Ireland \\ Correspondence to: U. Strohmayer (ulf.strohmayer@nuigalway.ie)
}

Received: 6 March 2015 - Accepted: 27 March 2015 - Published: 5 May 2015

Benedikt Korf's recent invitation to re-think the deployment of Heidegger's philosophy within geography in the pages of this journal (Korf, 2014) is both opportune and essential: opportune, because the many and continuing controversies surrounding Heidegger's political stance have been reignited following the on-going publication of his Schwarze Hefte (Heidegger, 2014a, b, and c); essential, because any invocation of "Heidegger" today arguably involves something additional to a reflection of the man, his politics, Weltanschauung and philosophy. What is also called for is a discussion of the conditions facilitating meaningful discourse about the nexus between "politics" and "knowledge". Heidegger's own construction of that nexus increasingly requires little by way of explanation: his involvement with National Socialism before, during and after his acceptance and subsequent relinquishing of the rectorship of Freiburg University in 1933, his refusal directly to comment on the Holocaust in the aftermath of World War II and the lack of support offered to his previous mentor and predecessor Edmund Husserl throughout the 1930s all speak volumes about just how the public person Heidegger saw fit to engage with politics. What is new, today, is that we can substantiate the charge of anti-Semitism given repeated pronunciations of undeniably anti-Semitic character in the Schwarze Hefte.

Readers unfamiliar with these latter and developing a sense of curiosity in the aftermath of Korf's opening salvo might appreciate the reference to a well-assembled archive of sorts available within Wikipedia's growing universe at https://de.wikipedia.org/wiki/Schwarze_Hefte, as well as the identification of a highly readable, personal review by Krell (2015); for the rest of us geographers, the questions posed by Korf remain enigmatic and difficult to answer given the ethical and political dimensions they invoke and entail. Invited to contribute to a debate about the "poison" of Heidegger's thought in critical geography, it is perhaps important initially to establish the place of Heidegger - or of "Heidegger" - in geography before we consider the present situation.
Scare quotes indeed, for is not the question whether we can separate the man from the signifier associated with a particular form of philosophy and vice versa?

Heidegger's reception within geography, we ought to remember, did not for the longest time separate the two, opting to concentrate on the latter while all but blanking out the former. In this, geography was not exceptional: the potential blemish arising from an equally potential involvement in National Socialism did not unduly occupy Heideggerians for a long time. Geography's encounter with Heidegger was furthermore a highly selective one that focused mostly on Heidegger's post-1930 "later" and allegedly "humanist" writings - and took place mostly in the worlds of Englishspeaking geography. With notable, mostly recent exceptions that inform the present contribution (Elden, 2005a; Shaw, 2012; Joronen, 2013; see also Strohmayer, 1998; Malpas, 2006 and Schatzki, 2007), geographers typically read Heidegger's philosophy to represent a contribution to "humancentred" forms of a "practice-based" geography. Given Heidegger's post-World-War-II use of grounded terminologies that equated language with the "house of being", critically deployed and developed notions of "dwelling," "building" or "lived space" more generally, this will not surprise any geographer (selected examples and surveys include Relph, 1976 and 1985; Buttimer, 1976; Entrikin, 1976; Seamon, 1979; Paddock, 2004; this selective engagement has also led - arguably in the form of a detour through the Deleuzian re-interpretation of Heidegger's "event" - to an embrace of neo-vitalist geographies of "affects" and "emotions", Joronen, 2013:628). If anything, the nature of this encounter rendered a critique of Heidegger the man less likely, even when a more nuanced assessment of his involvement in German politics began to emerge outside of Germany (for a case of benign neglect, see Gould, 1985); it would seem to be fair to say that for many, geographers and non-geographers alike, knowledge about Heidegger's involvement with National Socialism did not matter all that much until fairly recently; in 
the words of Joshua Rothman: "When I read Heidegger's books, I "knew" - but didn't particularly care - that he had been a Nazi" (Rothman, 2014).

More important than this lack of attention was the fact that the association of geography with "Heidegger" through the lenses of his later oeuvre initially led to a nonphenomenological embrace of "positive" or "enabling" traits characterising human existence, rather than an engagement with the critical investigation of conditions of possibility for such traits to become objects for human inquiry, which had characterised the work of Heidegger until the early 1930s (see Pickles, 1985, for an early critique of this stance). In this, geography's engagement mirrored that of Heidegger's own writings in the 1940s and 1950s by engaging with the world not in a critical, contingent manner but by asserting its key fundamental properties instead. Given that this turn or Kehre (see Sheehan, 2010) away from a critique of metaphysics towards a more fundamental abandonment of the philosophical subject and an embrace of a being's calling (see Wheeler, 2014) may well have been instrumental in, or inversely a result of, Heidegger's embrace of Nazism (see Habermas, 1990:156, for a polemical take on a similar line of inquiry), such a systemic blindness may well help to explain how and why Martin Heidegger and "Heidegger" could be kept separate for the longest time.

However, leaving aside the kind of speculation that clearly cannot be addressed in the space accorded to this brief intervention, we should take note of another, geographically interesting angle to the influence of Heidegger in geography. The effective neglect of the Heidegger of Being and Time and earlier texts circumscribing the outer contours of phenomenology (notably his 1927 Marburg lectures published as The Basic Problems of Phenomenology; see Heidegger, 1982) has had the somewhat unfortunate consequence of eliminating the key epistemological question of boundaries from our engagement with "Heidegger", an issue arguably also characterising his unwillingness to clearly distinguish political positions and act in accordance with such a differentiation. Heidegger's insistence on the centrality of "the decision" (see Heidegger, 1989:90) notwithstanding, references to acts of distinction ("Unter-scheidung") or decision ("Entscheidung") have never really become central to geography's engagement, despite the eminently geographical dimensions attached to the notion of "Scheidung" (separation or divorce) and its implied creation of metaphorical and real borders or boundaries.

Of course, the insistence on the role and potential importance of exclusionary and facilitating boundaries in Heidegger is - no pun intended - bound to refocus critical thought away from the candidates customarily associated with "Heideggerian" content and onto the facilitating epistemology instead. Instead of "house" or "dwelling", we would discuss that which surrounds and thus creates a house instead: the conditions of possibility of housing in the first place. We would, in other words, start from critique rather than from a position affirming purported unbounded common ground. The nub of this insistence would thus not just recognise that the outer contours of Heidegger's thinking are intricately tied in with and bounded by Greco-Germanic linguistic cultures, it would furthermore focus on a pronounced lack of curiosity by the master from Todtnauberg to step outside these bounds and explore that which was not already potentially at home within that tradition. The "rootedness" and "provinciality" associated with Heidegger's embodied being-in-theworld are significant in this regard, not because they link up with anti-modernist tendencies but because they serve as pointers towards a highly specific openness that makes room and thus frames its own emergence as distinct rather than as "merely happening". Distinctions require boundaries even where they claim to be of a fundamental, "ontological" kind, thus formulating the conditions of possibility for distinctions as such.

In all of these considerations of cultural or other boundaries, it is perhaps worth noting that any philosophy eager to retain a sense of "ownership" over its core ideas and concepts will have to be able to (or claim to be able to) control their outermost contours. Call this a residual epistemological authenticity that is implied more than pronounced - but not even a reflection on the conditions of possibility of thinking and not even Heidegger could do without these. That is, of course, assuming that he wanted to do without: vanity alone or concerns over the legacy of his Fundamentalphilosophie might easily have gotten in the way. If so (and we lack the time, the skills and the desire to psychologise), the boundaries accepted by Heidegger, as well as their interpretation during his time of writing, may well have furnished a convenient frame from which to derive and exercise the required means of control. It is within these boundaries, in other words, that we can begin to ascribe attributes to the event and thus "own" or "know" that which is unique - eigen - to the Ereignis. Even the post-Kehre Heidegger, interested less in comprehending the outer bounds of everyday phenomenology from within than to think the uncontrollable but imperative encounter with Being as such, was constantly struggling with just such boundaries between being ("Sein" now rechristened "Seyn") and nothingness ("Nichts") or between thinking and "mere prattle" (Heidegger, 2014a:10). Post-Kehre, establishing such boundaries more often than not required some form of struggle or "Ermächtigung" (ibid., 20) for it to lead anywhere (with some kind of guide or Führer becoming essential; ibid.). Crucially, one need not ascribe any "authenticity" to what emerges from this process for it to acquire meaning: it works best when hidden from view and thus implied in what is being communicated.

Jacques Derrida would later refer to such unacknowledged essentials as constituting the "blind spots" that institutionalise "supplements" in a philosophy (see Derrida, 1982:228; see also 1981). Heidegger's “Germanness”, his unquestioned privileging of certain traditions over others and the resulting highly selective "Eurocentrism", constitutes just one such 
blind spot (but see Sánchez, 2013); what remains important, not just for geographers, is the epistemological impossibility of avoiding boundaries in the constitution of such "blind spots". At best we can render them visible and thus open to critique by others and ourselves. Whether Heidegger the philosopher engaged in such a critique is a moot point given that Heidegger the public person never even acknowledged the centrality of posing the question. Given Heidegger's publicised scorn for all things public, this absence will come as no surprise to anyone but leaves those of us insisting on some kind of public role for philosophy (and social theory) with a genuine quandary concerning the future of Heideggerian geographies.

What, thus, remains to be done? Redesignate chairs of philosophy named after Heidegger (Kaube, 2015)? Perhaps. More important, however, would appear to be the recognition of the unavoidability of boundaries and of a manifestly political dimension to debates surrounding space at whatever level of abstraction and depth. We need, in other words, to apply lessons learned in the sphere of discursive geopolitics to a more general epistemology of space that does not arrest its own thinking by positing a more fundamental ontology of space impossibly located beyond boundaries (see Paasi, 1998 and 2013; the essays published in Houtum et al., 2005; Elden, 2005b; for a non-geopolitical translation, see Ingold, 2008). An open engagement with Heidegger's notion of politics may well become instrumental here: according to the Schwarze Hefte (1931-38), overcoming the "metaphysics of Dasein" requires its innermost broadening and deepening to become a "metapolitics "of" a historical people" (Heidegger, 2014a:124; the quotes are in the original; "politics" as such first emerges on page 22 as the act of "taking sides with true existentially minded people ("Existenziellen") against scientific philistines ("Banausen")). Coming from a decidedly unpolitical philosopher with a stated scorn for all things public, readers may well begin to wonder. More interesting still are the means anticipated by Heidegger to sustain such a metapolitics: according to Niall Keane's recent analysis based on Heidegger's engagement with the works of Ernst Jünger, these involved a markedly different conceptualisation of the act of drawing a "line" ("Linie"), not in terms of a heroic topography but in the form of a serene topology instead (Keane, 2015, ms 8-9). Perhaps it is here - or "here" - that a geography interested in working with and against Heidegger in the 21st century can hope to find inspiration and creative stimulation?

Edited by: F. Klauser

Reviewed by: one anonymous referee

\section{References}

Buttimer, A.: Grasping the dynamisms of the lifeworld, Ann. Assoc. Am. Geogr., 66, 277-92, 1976.

Derrida, J.: Plato's Pharmacy, in: Dissemination, trans. B. Johnson, Chicago, University of Chicago Press, 61-172, 1981.

Derrida, J.: White Mythology: Metaphor in the Text of Philosophy, Margins of Philosophy, trans, Alan Bass, Chicago: U of Chicago P, 207-72, 1982.

Elden, S.: Contributions to geography? The spaces of Heidegger's Beiträge, Environ. Plann. D, 23, 811-827, 2005a.

Elden, S.: Missing the Point: Globalization, Deterritorialization and the Space of the World, T. I. Brit. Geogr. 30, 8-19, 2005b.

Entrikin, J. N.: Contemporary Humanism in Geography, Ann. Assoc. Am. Geogr., 66, 615-632, 1976.

Gould, P.: The present and future being of geography as a human science, Geoforum, 16, 99-107, 1985.

Habermas, J.: The philosophical discourse of modernity. Twelve lectures, Cambridge, MA, MIT Press, 1990.

Heidegger, M.: The Basic Problems of Phenomenology, trans. A Hofstadter, Bloomington, Indiana University Press, 1982.

Heidegger, M.: Beiträge zur Philosophie (Vom Ereignis), Gesamtausgabe 65, Frankfurt am Main, Klostermann, 1989.

Heidegger, M.: Überlegungen II-VI (Schwarze Hefte 1931-1938), Heidegger Gesamtausgabe 94, edited by: Trawny. P., Frankfurt am Main, Klostermann, 2014a.

Heidegger, M.: Überlegungen VII-XI (Schwarze Hefte 1938/39), Heidegger Gesamtausgabe 95, edited by: Trawny, P., Frankfurt am Main, Klostermann, 2014b.

Heidegger, M.: Überlegungen XII-XV (Schwarze Hefte 19391941), Heidegger Gesamtausgabe 96, edited by: Trawny, P., Frankfurt am Main, Klostermann, 2014c.

Houtum, H. V., Kramsch, O., and Zierhofer, W. (Eds.): B/ordering space, Aldershot, Ashgate, 2005.

Ingold, T.: Bindings against boundaries: entanglements of life in an open world, Environ. Plann. A, 40, 1796-1810, 2008.

Joronen, M.: Heidegger, event and the ontological politics of life, T. I. Brit. Geogr., 38, 627-638, 2013.

Kaube, J.: 'Martin? Edmund!', Frankfurter Allgemeine Zeitung, 27 Februar 2015.

Keane, N.: Metaphysics, Politics, and Nihilism in Heidegger and Jünger, paper given at the "Heidegger et 'les Juifs"' Conference, Centre Culturel Irlandais, Paris, 24 January 2015.

Korf, B.: Critical geography and the poison of Heidegger's thought, Geogr. Helv., 69, 145-146, doi:10.5194/gh-69-145-2014, 2014.

Krell, D. F.: Heidegger's Black Notebooks 1931-41, Res. Phenomenol., 45, 127-160, 2015.

Malpas, J.: Heidegger's topology, Cambridge, Polity, 2006.

Paasi, A.: Boundaries as social processes: territoriality in the world of flows, Geopolitics, 3, 69-88, 1998.

Paasi, A.: Borders and Border-Crossings, The Wiley Blackwell Companion to Cultural Geography, edited by: Johnson, N., Schein, R., and Winders, J., Chichester, John Wiley and Sons, 478-493, 2013.

Paddock, T.: Gedachtes Wohnen: Heidegger and cultural geography, Philosophy \& Geography, 7, 237-249, 2004.

Pickles, J.: Phenomenology, Science and Geography, Spatiality and the Human Sciences, Cambridge, Cambridge University Press, 1985. 
Relph, E.: Place and Placelessness, London, Pion, 1976.

Relph, E.: Geographical experiences and being-in-the-world: The phenomenological origins of geography, Dwelling, Place and Environment: Towards a Phenomenology of Person and World, edited by: Seamon, D. and Mugerauer, R., Dordrecht, Nijhoff, 15-31, 1985.

Rothman, J.: Is Heidegger contaminated by Nazism?, The New Yorker, 28 April 2014.

Sánchez, C. A.: On Heidegger's "Thin” Eurocentrism and the possibility of a "Mexican" philosophy, Radical Philosophy Review, 16, 763-780, 2013.

Schatzki, T.: Heidegger: Theorist of Space, Stuttgart, Steiner, 2007.

Seamon, D.: Phenomenology, geography and geographical education, J. Geogr. Higher Educ., 3, 40-50, 1979.
Sheehan, T.: The Turn, Martin Heidegger: Key Concepts, edited by: Davies, B. W., Durham, Acumen, 82-101, 2010.

Shaw, I. G. R.: Towards an eventual geography, Prog. Hum. Geog., 36, 613-627, 2012.

Strohmayer, U.: The event of space. Geographic allusions in the phenomenological tradition, Environ. Plann. D, 16, 105-121, 1998.

Trawny, P.: Irrnisfuge, Berlin, Matthes \& Seitz, 2014.

Wheeler, M.: Martin Heidegger, The Stanford Encyclopedia of Philosophy (Fall 2014 Edition), edited by: Zalta, E. N., available at: http://plato.stanford.edu/archives/fall2014/entries/heidegger, 2014. 